\title{
Evaluation of serum fucose and protein bound fucose on myocardial Received: 1/3/2010 infarction patients in Erbil city \\ Accepted: 3/6/2011
}

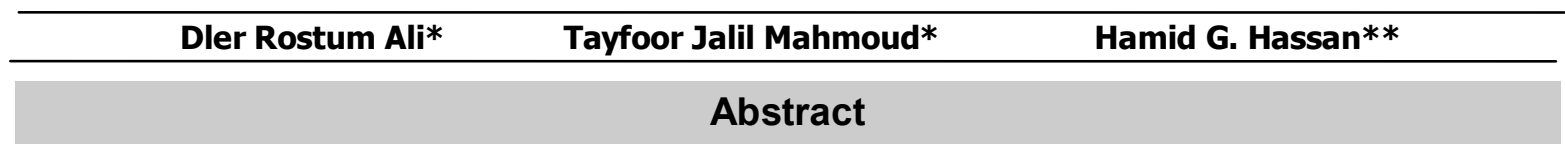

Background and objectives: L-fucose is a methyl pentose similar to L-galactose, except for the loss of the alcohol group on carbon No.6. It is found in human serum bound to proteins by covalent bonding and it is a member of a large group of compounds known as glycoproteins. Glycoproteins determine and steer up the vital functions of plasma membranes, e.g. cell-cell recognition, growth control, information uptake mediated via hormones or toxins and the attachment of antibodies. The aim of the current study is to measure the serum concentrations of these parameters on both the healthy individuals and the myocardial infarction patients.

Methods: The existing study has been initiated and implemented in earnest over the period commenced from February 2009 to October 2010 materialised on 100 healthy volunteer individuals countered to 110 (newly diagnosed myocardial infarction) patients. Serum total fucose and protein bound fucose were measured by UVIVIS spectrophotometery.

Results: The mean concentrations of serum fucose and protein bound fucose were significantly being higher on myocardial infarction patients versus those of the control individuals.

Conclusion: in order to envisage the negative impact on the heart muscle can be judged by the increase in serum level of fucose and the subsequent protein bound fucose on the myocardial infarction patients, thus, they can be labelled as the biomarkered for the myocardial infarction.

Key words: TF, PBF and MI.

\section{Introduction}

Myocardial infarction (MI) signifies the death of part of the heart muscle due to the interruption blood supply most commonely due to occlusion (blockage) of coronary artery causing the heart muscle to die. Without prompt immediate treatment, this can cause damage to the affected part of the heart, and leads eventually to heart attack. An Ml is sometimes called a heart attack or a coronary thrombosis. ${ }^{1}$ A heart attack occurs when one or more of the coronary arteries that supply blood to the heart are completely blocked and blood to the heart muscle is cut off ${ }^{2,3}$, therefore it occurs when myocardial cells have reached the threshold for ischemia; which in turn causes the body's myocardial cell turnover mechanism to be overwhelmed and completely fail. When this mechanism fails, myocardial tissue necrosis causing irreparable tissue/cell death occurs. ${ }^{4}$ About one fifth of all heart attacks are silent, that is, the victim does not know when the attack has been occurred. Although the victim feels no pain, silent heart attacks can still damage the heart, so infarction occurs in the absence of physical signs. ${ }^{2,5}$ L-fucose is a methyl pentose similar to L-galactose, except for the loss of the alcohol group on carbon No.6. It is found in human serum bound to proteins by covalent bonding and it is a member of

\footnotetext{
*Department of Clinical Biochemistry, College of Medicine, Hawler Medical University, Erbil, Iraq.

**Department of Biochemistry, Ibn Al-Haitham College, Baghdad University, Baghdad, Iraq.
} 
a large group of compounds known as glycoproteins. In a typical plasma glycoprotein, oligosaccharide side chains are attached to an oligosaccharide core, which, in turn, is bound by a glycopeptides bond and in every case involves carbon 1 of the most internal sugar ${ }^{6}$.<smiles>CC(O)C(O)C(O)C=O</smiles>

Structure of L-fucose.

Fucose is one of the eight essential sugars (Glucose, Galactose, Mannose, Fucose, Xylose, N-Acetylglucosamine, $\mathrm{N}$-A cet ylgalactosamine, and $\mathrm{N}$-Acetylneuraminic acid). The body requires this sugar for optimal function of cell- cell communication. The L- form is the only common form of the sugar, while the $D$ -form is a synthetic galactose analogue. ${ }^{7}$ Reports of the research work done in this field, revealed that the serum concentrations of serum total fucose (TF) and protein bound fucose (PBF) were being increased and it has been suggested that the serum total fucose and protein bound fucose can be used as laboratory biomarkers in a variety of pathological conditions such as breast cancer ${ }^{8}$, leukemia ${ }^{9}$, diabetes mellitus $^{10}$, gastric ulcers ${ }^{11}$, and cirrhosis 11,12. Glycoproteins determine characteristic functions of plasma membranes, e.g. cell-cell recognition, growth control, information uptake mediated via hormones or toxins and the attachment of antibodies.

${ }^{13}$ Fucose is a type of sugar that may be external or internal in both $\mathrm{N}$ - and O-linked glycoproteins, linked to the $\mathrm{N}$-acetylglucosamine (GlcNAc) residue, attached to asparagine (Asn) in $\mathrm{N}$-linked species. Can also occur internally attached to the $-\mathrm{OH}$ of serine (e.g. certain clotting factors). ${ }^{14}$ The plasma membranes of eukaryotic cells contain carbohydrates that are covalently linked to both lipid and protein components. Depending on the species and cell type, the carbohydrate content of the plasma membrane ranges between 2 and 10 percent by weight. More than 90 percent of the membrane's carbohydrate is covalently linked to proteins to form glycoproteins; the remaining carbohydrate is covalently linked to lipids to form glycolipids. All of the carbohydrate of the plasma membrane faces outward into the extracellular space. ${ }^{15}$

\section{Methods}

Subjects: This study was conducted from February 2009 to October 2010 at the department of medical biochemistry/ college of medicine/ Hawler medical university/ Erbil/ Iraq. The current survey has been carried out on (210) volunteers, which were divided into two groups:

Group I (Control group): One hundred randomly selected subjects (70 males and 30 females) were served. All are apparently healthy volunteers.

Group II (MI patient group): One hundred and ten (76 males and 34 females) MI patients (diagnosed by consultants) were participated in the study. Details concerning both groups are shown in Table 1:

Table 1: Details of number and age of both groups.

\begin{tabular}{cccc} 
Groups & Number & $\begin{array}{c}\text { Age } \\
\text { range } \\
\text { (years) }\end{array}$ & Mean $\pm S E$ \\
\hline Normal & 100 & $35-75$ & $53.28 \pm 5.97$ \\
MI patients & 110 & $38-80$ & $65.31 \pm 6.03$
\end{tabular}

2-Samples: Eight to ten milliliters of peripheral blood samples were drawn in the morning from controls and Ml patients using disposable syringes. The samples were transferred into glass tubes, quitting for (30) minutes for clotting and centrifuged at $3000 \mathrm{rpm}$ for (15 minutes). The separated serum was used for measurement of serum TF and PBF. 
3-Methods: Serum TF was estimated according to the method of Dische and shettels. ${ }^{15}$

Principle: The principle depends on the formation of a chromogen after addition of concentrated $\mathrm{H}_{2} \mathrm{SO}_{4}$ and cysteine reagent into the tube containing the sample and the color product measured at $(396-430 \mathrm{~nm})$. The difference in absorbance was directly proportional to $\alpha$-L-fucose content of the sample.

\section{Procedure:}

1. To $0.1 \mathrm{ml}$ ice cold serum, $4.5 \mathrm{ml}$ of chilled solution $\left(83 \% \mathrm{H}_{2} \mathrm{SO}_{4}\right)$ was added slowly with constant shaking in ice bath (to prevent arise in temperature).

2. The tubes were transferred to a water bath at room temperature for few minutes, and then to vigorously boiling for exactly three minutes, the tubes were then placed in water bath at room temperature for 5 minute.

3. One-tenth $\mathrm{ml}$ of $3 \%$ cysteine hydrochloride was added to each tube then mixed. After two hours the absorbance was read at $396 \mathrm{~nm}$ and $430 \mathrm{~nm}$.

4. The same procedure was applied for standard fucose solution $(10 \mathrm{mg} / \mathrm{ml})$.

\section{Calculations:}

$$
\text { Serum TF }(\mathrm{mg} / \mathrm{dl})=\frac{\text { Ax at } 390 \mathrm{~nm}-\mathrm{Ax} \text { at } 430 \mathrm{~nm}}{\text { Ast at } 390 \mathrm{~nm}-\text { Ast at } 430 \mathrm{~nm}} \times 12
$$

Where $A x=$ Absorbance of the unknown.

Ast $=$ Absorbance of the standard.

$12=$ Dilution factor.

Serum concentration of PBF was also determined for the two groups according to the method of Dische and shettels ${ }^{15}$.

Principle: After precipitating the protein by ethanol, a color product was formed by fucose in strong acid medium, which combines with color developer (cysteine hydrochloride). The color product with cysteine is measured at 396 and $430 \mathrm{~nm}$.

\section{Procedure:}

1. One $\mathrm{ml}$ of $95 \%$ ethanol was added to $0.1 \mathrm{ml}$ of serum for protein precipitation, centrifuged for $20 \mathrm{~min}$, at $3000 \mathrm{rpm}$, to get a clear solution.
2. The supernatant was decanted and washed with $1 \mathrm{ml}$ of $95 \%$ Ethanol then centrifuged again.

3. The supernatant decanted, the precipitate was re-suspended in $3 \mathrm{ml}$ of $0.1 \mathrm{~N}$ $\mathrm{NaOH}$ to re-solubilize the proteins.

4. One $\mathrm{ml}$ of the above solution was placed into two test tubes, $4.5 \mathrm{ml}$ of concentrated $\mathrm{H}_{2} \mathrm{SO}_{4}$ was added, then the mixture was boiled in water bath for three minute. A colored product was obtained.

5. Duplicate test tubes were cooled using tap water and $0.1 \mathrm{ml}$ of $3 \%$ cysteine hydrochloride was added to one of the test tubes and mixed.

6. The absorbance was read against distilled water at $396 \mathrm{~nm}$ and $430 \mathrm{~nm}$ respectively.

Serum PBF $(\mathrm{mg} / \mathrm{dl})=\frac{(\mathrm{Ax} \text { at } 390 \mathrm{~nm}-\mathrm{Ax} \text { at } 430 \mathrm{~nm})-}{\text { Ast at } 390 \mathrm{~nm}-}$
$\frac{(\text { Ay at } 390 \mathrm{~nm}-\text { Ay at } 430 \mathrm{~nm})}{\text { Ast at } 430 \mathrm{~nm}} \mathrm{X}_{12}$

Where $A x=$ Absorbance of the unknown sample with cysteine.

Ay = Absorbance of the unknown sample without cysteine.

Ast $=$ Absorbance of the standard. $12=$ Dilution factor.

\section{Results}

Table 2: provides the mean serum TF concentrations in both groups. The results obtained reveal that the mean serum TF was $(30.817 \pm 6.79 \mathrm{mg} / \mathrm{dl}$ in $\mathrm{Ml}$ patients, these values exceed significantly $(P<$ $0.01)$ than those obtained in normal group, $($ mean $=14.772 \pm 3.341 \mathrm{mg} / \mathrm{dl})$. On the other hand the mean serum level of TF in MI patients was two folds more than that of normal subjects, and serum TF concentration showed an increase in about $52 \%$ of MI patients. However there was no significant difference $(P>0.01)$ between males and females in both groups. Table (2) shows also the mean serum PBF concentrations in both groups. The data 
obtained indicate that the mean serum PBF was $(13.51 \pm 3.76 \mathrm{mg} / \mathrm{dl})$, (Mean $\pm \mathrm{SD})$ in MI patients. This value exceeds significantly $(P<0.01)$ that obtained in normal group $(9.932 \pm 1.69 \mathrm{mg} / \mathrm{dl})$. The mean serum level of PBF in MI patient was 1.3 folds more than that of normal subjects and serum PBF showed an increase in about $26.5 \%$ of Ml patients. However there was no significant difference $(P>0.01)$ between males and females in both groups.

Table 2: Details of serum TF and PBF (Mean \pm SD) in normal and Ml groups

\begin{tabular}{|c|c|c|c|}
\hline \multirow[t]{2}{*}{ Groups } & No. & $\begin{array}{l}\text { Serum } \\
\text { fucose } \\
\text { (mg/dl) }\end{array}$ & $\begin{array}{c}\text { Serum } \\
\text { PBF } \\
\text { (mg/dl) }\end{array}$ \\
\hline & & Mean $\pm S . D$ & Mean $\pm S . D$ \\
\hline
\end{tabular}

$\begin{array}{ccccc}\text { Normal } & 100 & 14.772 \pm 3.341 & 9.932 \pm 1.69 & \\ \begin{array}{c}\text { MI } \\ \text { group }\end{array} & 110 & 30.817 \pm 6.79 & 13.51 \pm 3.76 & <0.01\end{array}$

\section{Discussion}

The mean serum TF concentration in MI patients was significantly higher than that of control subjects $(P<0.01)$. This result is in agreement with that of Lindberg et al. ${ }^{16}$ who studied the serum level of sialic acid and fucose in atherosclerotic patients and found an increase in Ml patient. The serum TF comes mostly from the liver, and many researchers showed the possibility of using serum TF as a biomarker of many diseases such as breast cancer ${ }^{8}$, leukemia ${ }^{9}$, diabetes mellitus ${ }^{10}$, gastric ulcers ${ }^{11}$, and cirrhosis. ${ }^{11,12}$ Elevated serum TF might result either from the shedding or secreting of fucose from the cell membrane surface, or releasing of cellular fucose from the cell into the blood stream due to cell damage after myocardial infarction. ${ }^{17}$ The mean serum PBF in Ml patients was significantly higher than that of control subjects $(P<$ $0.01)$. Similar results were obtained by Snyder et al. 17 The level of serum glycoproteins has been shown to correlate with coronary atherosclerosis, and with atherosclerosis-related conditions such as peripheral vascular disease, diabetes and hypertriglyceridemia ${ }^{16}$. Thus, it is suggested that the increase in serum levels of PBF may be due to glycosylation of proteins or may be due to biosynthesis of glycoproteins in liver in Ml patients ${ }^{18}$.

\section{Conclusion}

As a result of this study, the following conclusions are drawing:

1. Estimation of the serum TF and PBF are easy and reliable methods.

2. The mean serum TF and PBF in Ml patients were significantly higher than that of controls. So their measurements may be used as a biomarker in the diagnosis of MI.

\section{References}

1. Tim K. and Beverley K. http://www.patient.co.uk/ health/Myocardial-Infarction-(Heart-Attack).htm. 2010.

2. Kannel W. B. Silent myocardial ischemia and infarction: insights from the Framingham Study. Cardiol. Clin. 1986; 4 (4): 583-91.

3. Elena B., Yochai B. and Joseph E. Electrocardiographic diagnosis of acute myocardial infarction: Current concepts for the clinician. American Heart Journal 2001; 141(4): 507-17.

4. Jonathan K. Diagnosis of acute myocardial infarct with ventricular paced rhythm. Emergency Medicine 2003; 15(1): 100-03.

5. Peter L, Robert O. B, Douglas L. M. and Douglas P. Z. Braunwald Heart Disease: a textbook of cardiovascular medicine, $8^{\text {th }}$ edition, W.E.Saunders, Philadelphia, USA, 2007.

6. Daniel J. and John B. Fucose: biosynthesis and biological function in mammals. Glycobiology 2003; 13(7): 41-53.

7. Alan W. Fucose. e-Newsletter. American International Association of Nutritional Education, (www.aianeduc.com), 2006.

8. Francis E., Murray S., James M. and Ernest F. Serum fucose in the diagnosis of breast cancer. Cancer 1971; 28: 1575-79.

9. Abbas L. B. Changes in $\alpha-L-F u c o s e$ and related parameters level in leukemia. Phd thesis, University of salahaddin, College of medicine-ErbilIraq.2004

10. AL-Haidary S. M. Evaluation of $\alpha$-L-Fucose and related parameters in different types of diabetes mellitus). MSc. thesis, Baghdad University Ibn ALHaitham College of education Iraq.2004 
11. Takeshi S., Kazuki Y., Hiroko Y., Kanako H., Fumitsugu H., et al. Rapid, simple enzymatic assay of free L-Fucose in serum and urine, and its use as a marker for cancer, cirrhosis, and gastric ulcers. Clinical Chem. 1990; 36(3): 474-76.

12. Vijayalakshmi S., Geetha A. and Annie S. J. A biochemical study on the level of lipids and glycoproteins in the serum and platelets of liver cirrhotic bleeders. Acta Biochimica Polonica. 2006; 53(1): 213-20.

13. Peter $V$. and Werner R. Different turnover of fucose residues in plasma membranes of rat liver and morris hepatoma 7777. Biochem. J. 1980; 190: 51-55.

14. Robert K., Daryl G., Peter A. and Victor W. Harper's Illustrated Biochemistry. $26^{\text {th }}$ edition, McGraw-Hill, USA, 2003.

15. Dische Z. and Shettles L. A specific color reaction of methylpentoses and a spectrophotometric micromethod for their determinations. J. Biol. Chem. 1948; 175: 595-603.

16 Lindberg G., Rastam L., Nilsson-EhleSerum P. et al. Sialic acid and sialoglycoproteins in asymptomatic carotid artery atherosclerosis. Atherosclerosis 1999; 146: 65-69.

17. Snyder S., Coodley E., Durham B., and pennock R. Serum glycoproteins in coronary artery disease. Circulation. 1977; 56(3): 359-62.

18.Mukesh N., Ojha1 S., Ranjit K. Changes in levels of serum glycoproteins in major depressive disorders. Indian Journal of Clinical Biochemistry. 2005; 20(2):154-157. 